\title{
COMMENTARY
}

\section{Blue carbon is not substantial in Australian kelp forests}

arising from P Filbee-Dexter, K. \& Wernberg, T. Sci Rep 10, (2020). doi:10.1038/s41598-020-69258-7.

John Barry Gallagher ${ }^{1}$ and Victor Shelamoff ${ }^{2}$

Institute for Marine and Antarctic Studies, University of Tasmania, 20 Castray Esplanade Battery Point, TAS 7004, Australia

Blue carbon refers to the greenhouse gas mitigation services, regarded as primarily supplied by seagrass, mangrove, and saltmarsh relative to a likely alternative ecosystem ${ }^{1}$. However, a recent study calculates that kelp forests across the Australian Great Southern Reef (GSR) represent globally significant blue carbon stocks and sequestration services, suggesting that these ecosystems should be explicitly included within the blue carbon conceptual model. The article brings together data on the ostensibly Ecklonia radiata assemblage of the GSR in a worthy attempt to quantify the magnitude and importance of these systems as carbon sinks. Their sequestration calculations are based on the fraction of Ecklonia's net primary production (NPP) that is either buried in adjacent sediments or exported away to the deeper parts of the ocean. The article also makes a carbon stock comparison between kelp forests and seagrass, mangrove, and saltmarsh ecosystems, which is based on the remnant standing biomass of these systems in Australia.

In our view this approach to assessing carbon sink mitigation services is both ill-founded and misleading. Firstly, blue carbon sequestration services should be based on any export and storage of excess carbon produced by the ecosystem, i.e., the fraction of its net ecosystem production (NEP), and not just the NPP of the kelp assemblage. NEP account for gross primary production and total respired $\mathrm{CO}_{2}$ across the ecosystem which for kelp forests includes micro-and-macro-algae as well as the associated benthic fauna. Secondly, the carbon storage comparison between kelp forests and other ecosystems (based on standing biomass) presented in the article fails to include seagrass, mangrove, and saltmarsh sediments where most of the carbon is stored. We attempt to clarify the apparent misconception around blue carbon by deconstructing the contribution of communities to primary production, respiration and carbon sequestration for the ecosystem. We also compile accessible data on seaweed ecosystems NEP to illustrate the consequences of not addressing the correct concept. 
The seminal paper by Duarte and Cebrian ${ }^{2}$ helped lay the foundations for blue carbon science by estimating the proportion of macroalgal NPP is transferred to consumers, stored in sediments, and exported to other systems. Underlying this analysis was a kelp assemblage that was not expected to wax and wane in any significant or deterministic manner over at least interannual scales ${ }^{3}$, and a system that was in balance (equation (1) below). The rate of carbon storage to its sediments was relatively minor, and the exported material as the $\mathrm{NEP}^{4}$ after the plant and consumer respiration (equations (2) and (3)), was assumed to be completely respired within the ocean. The value of mitigation services would then lay solely with the preservation of its standing biomass. More recently, it was calculated that a small fraction of the exported kelp litter is likely to be sequestered and stored away in the deep ocean ${ }^{5,6}$ (equation (4)). This fraction, together with a kelp ecosystem in a steady state that supports a $\mathrm{C}$ biomass over the long term, appears to be the basis for the articles' analysis. We contend that kelp forest NEP is not equivalent to the litter exported. In our view, the construct wrongly assumes that these ecosystems are closed to any form of respiratory subsidy. This could reduce NEP and potentially render the system heterotrophic (the term $\boldsymbol{\theta S} \boldsymbol{r}$, equation (5)). In other words, the ecosystem could move from being a sink to a source of $\mathrm{CO}_{2}$. Such subsidies to kelp production can conceivably be supplied from the kelp epibiont community from their mobile coastal benthic fauna as well as coastal water holoplankton ${ }^{7,8}$

We demonstrate the importance of likely subsidies by compiling and reanalysing data extracted from the literature that have or can provide measures of seaweed NEP (Table 1). Indeed, it was found that most measures of seaweed ecosystems were mildly heterotrophic, although some fucoid and tropical macroalgal systems appear to represent outlier autotrophic systems (Figure 1). Nonetheless, all of the studied systems supported significantly lower NEP than the average litter exported from macroalgal ecosystems, i.e., $43 \%{ }^{2}$ of their average NPP (around $\left.500 \mathrm{mmols} \mathrm{C} \mathrm{m}^{-2} \mathrm{day}^{-1}\right)^{9}$. Indeed, it could be argued that the use of chambers may have biased the population's examples towards a higher NEP median or mean than warranted. Benthic chamber enclosures, unlike open eddy covariance measurements: 1) isolate any export of litter and possibly reduce the amount of litter breakage and accumulation for detritivore respiration; 2) isolate any imports of animal and organic subsidies for community respiration; and 3) allow a net plant growth that would lead to an increase in carbon fixation over an ecosystem where biomass is constrained from seaweed breakage and export. 
Based on the data available, the value of seaweed ecosystem carbon sinks is not likely to come from their ability to sequester carbon, but from the persistence of their standing biomass. However, Filbee-Dexter and Wernbergs' contention that kelp forests contribute $11 \%$ to $13 \%$ of the total blue carbon stocks across Australia is misleading. Using standing biomass does not acknowledge the fact that accumulation of sediment carbon stocks within open coastal kelp forests is likely to be minimal, whilst for mangroves, seagrass, and saltmarsh a major fraction of carbon is stored in sediments. Using data from the same cited work as Filbee-Dexter and Wernberg, then accounting for the sedimentary carbon reduces the contribution to a little as $0.4 \%$ to $1.5 \%$.

$$
\begin{aligned}
& \mathrm{NES}=\mathrm{GPP}-\mathrm{Cr}-\theta \mathrm{E}=\mathrm{NPP}-\theta \mathrm{Dr}-\theta \mathrm{Hr}-\theta \mathrm{E}=0 \\
& \mathrm{NPP}=\mathrm{GPP}-\mathrm{Pr} \\
& \mathrm{NEP}=\mathrm{GPP}-\mathrm{Cr}=\mathrm{E} \\
& \mathrm{NES}=\phi \mathrm{E}=\phi \mathrm{NEP} \\
& \mathrm{NES}=\phi(\mathrm{NEP})=\mathrm{NPP}-\theta \mathrm{Dr}-\theta \mathrm{Hr}-\boldsymbol{\theta S} \boldsymbol{r}
\end{aligned}
$$

Where NEP is the net ecosystem production; GPP the gross primary production of the seaweed assemblage; $\mathrm{Cr}$ the plant and consumer respiration of the non-recalcitrant fractions $(\theta)$; Pr the respiration of the seaweed assemblage; Dr that fraction of ecosystems' organic carbon respired by detritivores; Hr that fraction of the ecosystems' organic carbon respired by herbivores; and Sr that fraction of the ecosystems' organic subsidies respired by both a sessile and mobile faunal community.

Based on these reported measurements and recalculations alone, we suggest that GSR kelp forests are unlikely to provide major blue carbon mitigation services. This is far from Filbee-Dexter and Wernberg estimate of $30 \%$ of the Australian blue carbon sequestration total, with one possible caveat. Ultimately, sequestration mitigation depends not on their absolute value, but the differences between a likely replacement ecosystem ${ }^{1,10}$. Indeed, across Australian GSR Filbee-Dexter and Wernberg point to a switch to alternative urchin barrens and turf algae dominated reefs, which appear to support low NEP values ${ }^{11,12,13}$. 
Table 1. Net ecosystem productivity of seaweed assemblages extracted from published literature from statistical summaries and extracted from figures after digitization using the platform GraphGrabber ${ }^{\mathrm{TM}}$ v2.0.1. NEP $=$ Net ecosystem productivity. ${ }^{\text {a }}$ Study results were recalculated for over a $9 \mathrm{hr}$ day and night. ${ }^{\mathrm{b}}$ Results were recalculated for over a $9 \mathrm{hr}$ day and night for understory and $M$. pyrifera assemblage NPP as biomass growth, assuming respiration rates of $M$. pyrifera component $=0.1 \mathrm{GPP}^{20}$. The NEP are expressed as the mean \pm the standard error. All measurements based on $\mathrm{O}_{2}$ dynamics were corrected to $\mathrm{C}$ using a molar $\mathrm{O}_{2} / \mathrm{CO}_{2}$ quotient of 1 .

\begin{tabular}{|c|c|c|}
\hline Seaweed assemblage & $\begin{array}{l}\text { NEP } \\
\left(\mathrm{mmols} \mathrm{C} \mathrm{m}^{-2} \mathrm{day}^{-1}\right)\end{array}$ & Method \\
\hline $\begin{array}{l}\text { Canopy kelps Eualaria fistulosa and } \\
\text { understory }^{12}\end{array}$ & $-19.98 \pm 35.4$ & Benthic chambers \\
\hline $\begin{array}{l}\text { Canopy kelps Macrocystis pyrifera } \\
\text { and Ecklonia arborea) Sargassum } \\
\text { horneri }^{14}\end{array}$ & $-1.84 \pm 3.66$ & Benthic chambers \\
\hline Seaweed rack Fucus vesiculosus ${ }^{15}$ & $+11.2 \pm 12.4$ & Aquatic eddy covariance \\
\hline Seaweed rack Fucus vesiculosus ${ }^{15}$ & +65.98 & Aquatic eddy covariance \\
\hline 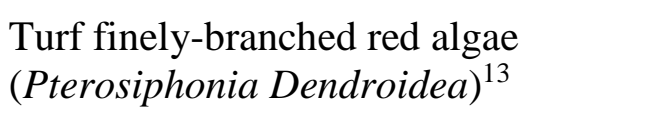 & -97.44 & Benthic chambers $^{\mathrm{a}}$ \\
\hline $\begin{array}{l}\text { Foliose blade forming red algae } \\
\text { Chondracanthus corymbiferus and } \\
\text { Rhodymenia californica }\end{array}$ & -51.15 & Benthic chambres $^{a}$ \\
\hline $\begin{array}{l}\text { Canopy kelp Macrocystis pyrifera, } \\
\text { understory kelps Pterygophora } \\
\text { californica, Laminaria farlowii, and } \\
\text { red algae Chondracanthus } \\
\text { corymbiferus, and Rhodymenia } \\
\text { californica }^{17}\end{array}$ & -15.15 & Benthic chambers ${ }^{b}$ \\
\hline $\begin{array}{l}\text { Brown seaweed Sargassum sp. with } \\
\text { some fleshy macroalgae, coralline } \\
\text { algae, and } 10 \% \text { coverage as coral }{ }^{18} \text {. }\end{array}$ & $+10.0 \pm 5.0$ & $\begin{array}{l}\text { Eulerian and atmospheric exchanges of } \\
\text { the oxygen }\end{array}$ \\
\hline $\begin{array}{l}\text { Canopy Kelp Ecklonia and luminaria } \\
\text { sp. ecosystem, including macroalgal } \\
\text { understory and phytoplankton }{ }^{19}\end{array}$ & -17.70 & $\begin{array}{l}\text { Calculated carbon balance between } \\
\text { primary producers and consumer } \\
\text { demands }\end{array}$ \\
\hline
\end{tabular}




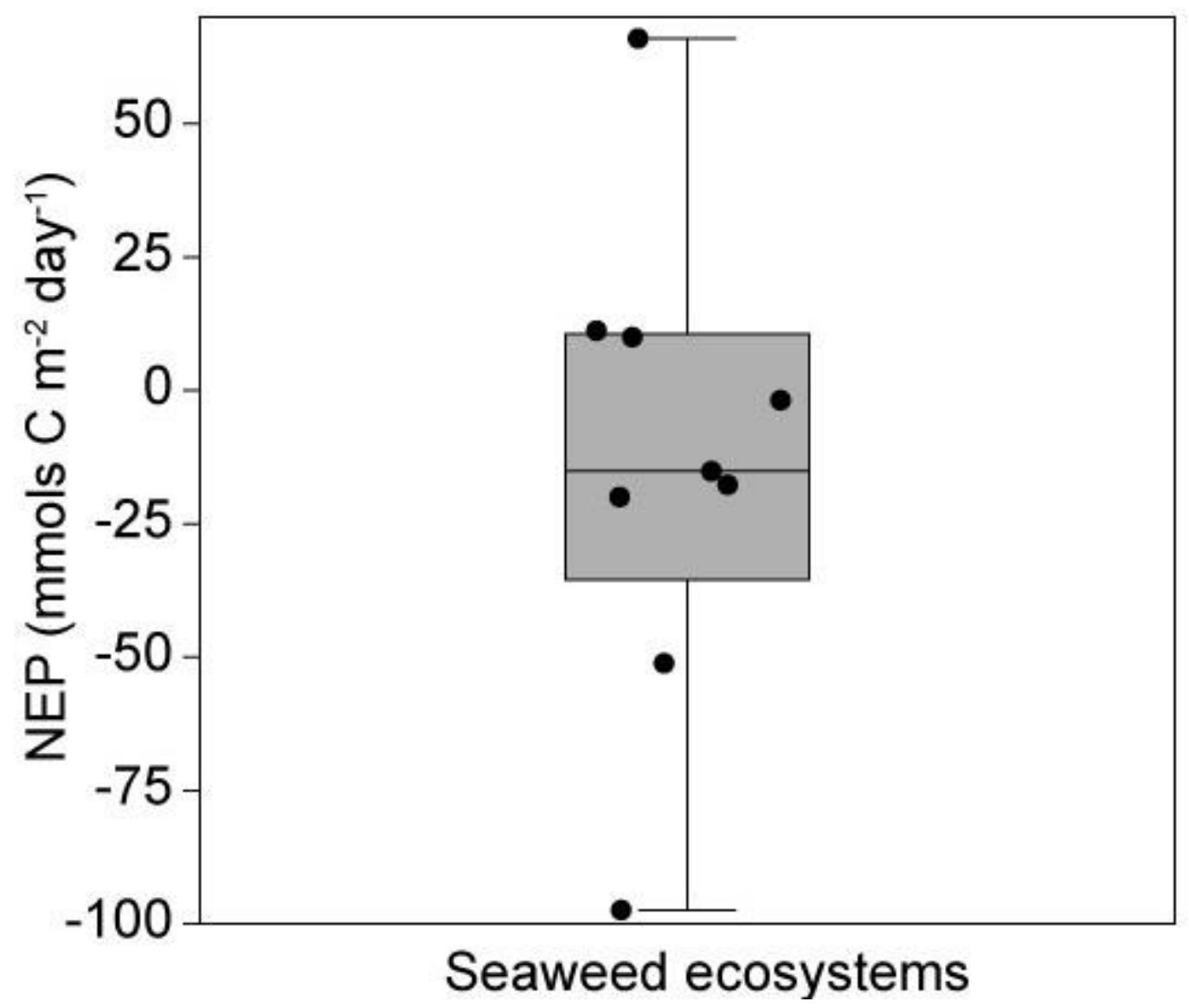

Figure 1. The variance of reported and re-calculated NEP (Table 1). The central statistic represents the median of -15.15 mmols $\mathrm{C} \mathrm{m}^{-2}$ day $^{-1}$, and the error bars are the $1^{\text {st }}$ and $3^{\text {rd }}$ quartiles of 35.6 to +10.6 mmols $\mathrm{C}$ $\mathrm{m}^{-2}$ day $^{-1}$. The outliers come from a cold temperate Baltic seagrass rack ecosystem and warm temperate Californian turf assemblage (Table 1). The figure was produced within PAST ${ }^{\mathrm{TM}}$ v4.01 and modified using Adobe Illustrator $\mathrm{CS}^{\mathrm{TM}}$.

\section{References}

1 Gallagher, J. B. Taking stock of mangrove and seagrass blue carbon ecosystems: A perspective for future carbon trading. Borneo Journal of Marine Science and Aquaculture 1, 71-74 (2017).

2 Duarte, C. M. \& Cebrián, J. The fate of marine autotrophic production. Limnology and Oceanography 41, 1758-1766, doi:10.4319/lo.1996.41.8.1758 (1996).

3 Gallagher, J. B. in Aquaculture Ecosystems (eds S. Mustafa \& R. Shapawi) Ch. 8, 243-280 (Wiley Blackwell, 2015).

4 Lovett, G. M., Cole, J. J. \& Pace, M. L. Is Net Ecosystem Production Equal to Ecosystem Carbon Accumulation? Ecosystems 9, 152-155, doi:10.1007/s10021-005-0036-3 (2006). 
Krause-Jensen, D. \& Duarte, C. M. Substantial role of macroalgae in marine carbon sequestration. Nature Geosci 9, 737-742, doi:10.1038/ngeo2790 (2016)

6 Gallagher, J. B. in International Conference on Marine Science and Aquaculture 2014: Ecosystem perspectives in sustainable development (ed S Mustaffa) 26-40 (Universiti Malaysia Sabah).

Allen, J. \& Griffiths, C. The fauna and flora of a kelp bed canopy. African Zoology 16, 80-84 (1981).

Zuercher, R. \& Galloway, A. W. E. Coastal marine ecosystem connectivity: pelagic ocean to kelp forest subsidies. Ecosphere 10, e02602, doi:10.1002/ecs2.2602 (2019).

9 Middelburg, J., Duarte, C. \& Gattuso, J.-P. Respiration in coastal benthic communities. Respiration in Aquatic Ecosystems, 206-224 (2005).

10 Siikamäki, J., Sanchirico, J. N., Jardine, S., McLaughlin, D. \& Morris, D. Blue Carbon: Coastal Ecosystems, Their Carbon Storage, and Potential for Reducing Emissions. Environment: Science and Policy for Sustainable Development 55, 14-29, doi:10.1080/00139157.2013.843981 (2013).

11 Attard, K. M., Glud, R. N., McGinnis, D. F. \& Rysgaard, S. Seasonal rates of benthic primary production in a Greenland fjord measured by aquatic eddy correlation. Limnology and Oceanography 59, 1555-1569, doi:10.4319/lo.2014.59.5.1555 (2014).

12 Edwards, M. et al. Marine deforestation leads to widespread loss of ecosystem function. PLoS One 15, e0226173, doi:10.1371/journal.pone.0226173 (2020).

13 Miller, R. J., Reed, D. C. \& Brzezinski, M. A. Community structure and productivity of subtidal turf and foliose algal assemblages. Marine Ecology Progress Series 388, 1-11, doi:10.3354/meps08131 (2009).

14 Sullaway, G. H. \& Edwards, M. S. Impacts of the non-native alga Sargassum horneri on benthic community production in a California kelp forest. Marine Ecology Progress Series 637, 45-57 (2020).

15 Rodil, I. F., Attard, K. M., Norkko, J., Glud, R. N. \& Norkko, A. Towards a sampling design for characterizing habitat-specific benthic biodiversity related to oxygen flux dynamics using Aquatic Eddy Covariance. PLoS One 14, e0211673, doi:10.1371/journal.pone.0211673 (2019). 
16 Attard, K. M. et al. Seasonal metabolism and carbon export potential of a key coastal habitat: The perennial canopy-forming macroalga Fucus vesiculosus. Limnology and Oceanography 64, 149-164, doi:10.1002/lno.11026 (2019).

17 Miller, R. J., Reed, D. C. \& Brzezinski, M. A. Partitioning of primary production among giant kelp (Macrocystis pyrifera), understory macroalgae, and phytoplankton on a temperate reef. Limnology and Oceanography 56, 119-132, doi:10.4319/lo.2011.56.1.0119 (2011).

18 Gruber, R. K., Lowe, R. J. \& Falter, J. L. Metabolism of a tide-dominated reef platform subject to extreme diel temperature and oxygen variations. Limnology and Oceanography 62, 1701-1717, doi:10.1002/lno.10527 (2017).

19 Newell, R., RC, N. \& JG, F. The contribution of bacteria and detritus to carbon and nitrogen flow in a benthic community. Marine Biology Letters 4, 23-36 (1983).

20 Gerard, V. A. Photosynthetic characteristics of giant kelp (Macrocystis pyrifera) determined in situ. Marine Biology 90, 473-482, doi:10.1007/BF00428571 (1986).

Author contributions.

John Barry Gallagher led the article, initiated the concept, compiled and analysed the dataVictor Shelamoff contributed to the text, its concept, data compilation, and the design of the table and figure.

Competing interests

This manuscript describes original work and is not under consideration by any other journal. All the authors, John Barry Gallagher and Victor Shelamoff approved the manuscript and have no conflict of interest in submitting the article, or a need for ethics approval. 